\title{
Response surface methodology modeling of protein concentration, coagulum cut size, and set temperature on curd moisture loss kinetics during curd stirring
}

\author{
Ram R. Panthi, ${ }^{1,2,3}$ Alan L. Kelly, ${ }^{2}$ Donald J. McMahon, ${ }^{3}$ Xin Dai, ${ }^{4}$ Almut H. Vollmer, ${ }^{3}$ \\ and Jeremiah J. Sheehan ${ }^{1 *}$ \\ ${ }^{1}$ Teagasc Food Research Centre Moorepark, Fermoy, Co. Cork, P61 C966, Ireland \\ ${ }^{2}$ School of Food and Nutritional Sciences, University College Cork, T12 YN60, Ireland \\ ${ }^{3}$ Western Dairy Center, Department of Nutrition, Dietetics and Food Sciences, Utah State University, Logan 84321 \\ ${ }^{4}$ Utah Agricultural Experiment Station, Utah State University, Logan 84322
}

\section{ABSTRACT}

The effects of the independent variables protein concentration (4-6\%), coagulum cut size $\left(6-18 \mathrm{~mm}^{3}\right)$, and coagulation temperature $\left(28-36^{\circ} \mathrm{C}\right)$ on curd moisture loss during in-vat stirring were investigated using response surface methodology. Milk $(14 \mathrm{~kg})$ in a cheese vat was rennet coagulated, cut, and stirred as per semihard cheesemaking conditions. During stirring, the moisture content of curd samples was determined every $10 \mathrm{~min}$ between 5 and 115 min after cutting. The moisture loss kinetics of curds cut to $6 \mathrm{~mm}^{3}$ followed a logarithmic trend, but the moisture loss of curds from larger cut sizes, 12 or $18 \mathrm{~mm}^{3}$, showed a linear trend. Response surface modeling showed that curd moisture level was positively correlated with cut size and negatively correlated with milk protein level. However, coagulation temperature had a significant negative effect on curd moisture up to $45 \mathrm{~min}$ of stirring but not after $55 \mathrm{~min}$ (i.e., after cooking). It was shown that curds set at the lower temperature had a slower syneresis rate during the initial stirring compared with curds set at a higher temperature, which could be accelerated by reducing the cut size. This study shows that keeping a fixed cut size at increasing protein concentration decreased the level of curd moisture at a given time during stirring. Therefore, to obtain a uniform curd moisture content at a given stirring time at increasing protein levels, an increased coagulum cut size is required. It was also clear that breakage of the larger curd particles during initial stirring can also significantly influence the curd moisture loss kinetics. Both transmission and scanning electron micrographs of cooked curds (i.e., after $45 \mathrm{~min}$

Received May 12, 2018.

Accepted February 4, 2019.

*Corresponding author: Diarmuid.sheehan@teagasc.ie of stirring) showed that the casein micelles were fused at a higher degree in curds coagulated at $36^{\circ} \mathrm{C}$ compared with $28^{\circ} \mathrm{C}$, which confirmed that coagulation temperature causes a marked change in curd microstructure during the earlier stages of stirring. The present study showed the dynamics of curd moisture content during stirring when using protein-concentrated milk at various set temperatures and cut sizes. This provides the basis for achieving a desired curd moisture loss during cheese manufacture using protein-concentrated milk as a means of reducing the effect of seasonal variation in milk for cheesemaking.

Key words: protein standardization, cut size, coagulation temperature, curd moisture loss kinetics, electron microscopy

\section{INTRODUCTION}

Application of membrane filtration systems to concentrate milk results in retention of the larger components (i.e., protein and fat) with removal of whey as permeate. Interest in application of UF in cheesemaking has increased (Heino et al., 2010; Govindasamy-Lucey et al., 2011; Ozturk et al., 2015) because it facilitates increased cheese plant throughput and helps to achieve greater cheese consistency despite seasonal variations in milk composition (Broome et al., 1998; Guinee et al., 2006). Milk of approximately $3 \%$ protein can be concentrated to approximately 4 to $5 \%$ protein (Guinee et al., 1994; Broome et al., 1998; i.e., low concentration ratio of 1.2 to 1.6 times the normal concentration) for cheesemaking using conventional industrial cheese vats and downstream equipment (Oommen et al., 2000; Govindasamy-Lucey et al., 2005). Higher ratios add complexity to the process and require specialized equipment (Mistry and Maubois, 2017). Standardizing milk above $5 \%$ protein presents challenges during cheesemaking because of increased curd firmness and the re- 
sultant altered dynamics of rennet-induced coagulation and whey expulsion from curds (Guinee et al., 1994).

The underlying mechanism of rennet-induced gel formation in milk is related to the formation of interconnected protein networks by the action of rennet. The resulting protein matrix enmeshes large components (e.g., fat globules) by stopping their mobility (Ong et al., 2011, 2013), whereas small components (e.g., lactose and minerals) diffuse from areas of higher concentration toward areas of lower concentration. Cheesemaking includes cutting a rennet-induced gel at suitable firmness into small curd pieces using cheese knives, followed by in-vat stirring to facilitate expulsion of entrapped water and whey (Dejmek and Walstra, 2004). In modern industrial cheesemaking processes, the time allowed for stirring in-vat (vat residence time) is standardized for different cheese types.

Expulsion of whey from the curds during stirring occurs due to contraction of the protein network (Fagan et al., 2017). Curd moisture content decreases in line with the level of whey expulsion (Mateo et al., 2009a). Studies on the rate of whey expulsion during in-vat stirring suggest various orders of kinetics (e.g., first order, second order, or higher; Caron et al., 2001; Huber et al., 2001; Thomann et al., 2006; Giroux et al., 2014), probably because of different factors that influence protein network contraction (Janhøj and Qvist, 2010).

Whey expulsion from curd is a complex process influenced by multiple factors, such as milk composition, temperature, $\mathrm{pH}$, rennet level, addition of $\mathrm{CaCl}_{2}$, and curd dimensions (Kaytanli et al., 1994; Thomann et al., 2006; Mateo et al., 2009a). Interactions between these factors critically affect the rate of moisture loss during in-vat stirring (Fagan et al., 2007; Giroux et al., 2014). At microscopic or macroscopic levels, moisture loss from a curd is related to breaking of protein-protein bonds, inducing microstructural changes in curds (Geng et al., 2011) and leading to the rearrangement of casein micelles in the protein network (Mellema et al., 2002). Cheesemaking from protein-standardized milk results in rapid gel firming and excessive firmness; however, the rate of whey expulsion has been reported to increase (Casiraghi et al., 1987), remain unchanged (Peri et al., 1985), or decrease (Calvo and Espinoza, 1999; Caron et al., 2001; Thomann et al., 2008) depending on the extent of milk concentration. Thus, this area would benefit from more studies, leading to greater understanding of the effects of process parameters on whey expulsion.

Temperature is an important factor that influences coagulation and whey syneresis (Castillo et al., 2006). Although temperatures for semihard cheesemaking are generally between 31 and $32^{\circ} \mathrm{C}$ for coagulation and 37 and $38^{\circ} \mathrm{C}$ for cooking, curd contraction rate increases with increasing temperature, which results in subsequent increases in whey expulsion (Huber et al., 2001; Giroux et al., 2014). Increasing protein concentration in milk further promotes rapid gel-firming rate and excessive firmness, potentially causing difficulty in curd handling during in-vat stirring (Guinee et al., 1994). Lowering of coagulation temperature has been used to normalize such coagulation properties in the case of UF-treated milk (Guinee et al., 1994; GovindasamyLucey et al., 2004, 2011).

Coagulum cut size is another important factor that influences whey expulsion. Curd particles of smaller size release whey faster compared with curd particles of bigger size (Grundelius et al., 2000). Coagula for hard cheese (which requires low moisture level in curds) are cut to cube sizes of 4 to $6 \mathrm{~mm}$ (Govindasamy-Lucey et al., 2004, 2011), whereas cube sizes for medium- to high-moisture cheeses vary between 11 and $21 \mathrm{~mm}$ (Renault et al., 1997; Grundelius et al., 2000). Therefore, curd size can be manipulated to adjust the rate or extent of whey expulsion (Renault et al., 1997; Johnston et al., 1998; Everard et al., 2008).

Although various methods for syneresis measurement are available (Fagan et al., 2017), measurement of curd moisture could offer more practical information for the selection of process conditions to achieve decision making for appropriate curd moisture content before drainage. Previous studies have explored the possibility of prediction of real-time curd moisture (Mateo et al., 2009a) through sensors that are attached in-line to vats to achieve better control (Mateo et al., 2009b). Modeling of interactive effects of temperature, cut size, and protein concentration through response surface methodologies can provide insights to cheesemakers for optimization, minimization, or maximization of in-vat curd moisture content during stirring. An understanding of such interactive effects on moisture loss from curd when concentrated milk is used is particularly desirable because this determines the combination of conditions that can be used to achieve consistency in curd moisture levels during stirring.

Panthi et al. (2018) showed that, under constant $\mathrm{pH}$ and temperature conditions, curd moisture loss after cutting follows a power law trend. It is also known that less whey expulsion occurs at lower temperatures (Castillo et al., 2006; Giroux et al., 2014). To study the practical implications of increasing or reducing the coagulation temperature, a study was designed to (1) incorporate modern cheesemaking practices such as UF concentration of milk and standardization of $\mathrm{pH}$; (2) minimize initial $\mathrm{pH}$ change so that the model could focus on protein concentration, cut size, and set 
temperature; (3) use a fixed cook temperature; and (4) include a whey dilution step, such as that used for making Maasdam, Gouda, Swiss, and other cheeses, but separate from the cooking step. To achieve this, response surface methodology was used to investigate the interactive effects of protein level $(4,5$, and $6 \%$ ), coagulum cut size (6-, 12-, and 18-mm cubes), and coagulation temperature $\left(28,32\right.$, and $\left.36^{\circ} \mathrm{C}\right)$ on curd moisture loss kinetics during in-vat stirring along with characterization of the microstructure of the curds using electron microscopy.

\section{MATERIALS AND METHODS}

\section{Milk Collection and UF}

Fresh bovine milk was obtained from the George B. Caine Dairy Research and Teaching Center (Wellsville, UT) and transported to the Gary Haight Richardson Dairy Products Laboratory at Utah State University (Logan). The whole milk was first pasteurized at $73^{\circ} \mathrm{C}$ for $15 \mathrm{~s}$ and then $(\sim 180 \mathrm{~kg})$ circulated through an UF plant using spiral-wound polyethersulfone membranes with a $10-\mathrm{kDa}$ molecular weight cut-off (model ST$2-3838,10 \mathrm{~cm} \times 100 \mathrm{~cm}$ with a $0.76-\mathrm{mm}$ spacer, 7 $\mathrm{m}^{2}$ surface area; Synder Filtration, Vacaville, CA) at approximately $45^{\circ} \mathrm{C}$ until approximately $3 \times$ concentration was reached. Pasteurized skim milk was purchased from a local grocery in Logan, Utah. Whole milk, UF retentates, permeates, and skim milk were stored at $4^{\circ} \mathrm{C}$ until needed.

\section{Milk Standardization and Preparation}

Steps for milk preparation and cheesemaking procedure are schematically presented in Figure 1. Milks were standardized targeting to nominal protein levels of 4,5 , or $6 \%$ while maintaining a protein-to-fat ratio of approximately 1.0 by combining pasteurized whole milk, skim milk, and UF retentate in 14-kg rectangular cheese vats. The protein-to-fat ratio was chosen to target a semihard-type cheese manufacturing process for production of cheese with $45 \%$ fat in DM. Standardized milk $\mathrm{pH}$ varied between 6.72 and 6.77 , and this was adjusted to 6.5 by adding lactic acid (1:8 dilution, vol/ vol). Milk was then heated to $45^{\circ} \mathrm{C}$ and cooled to the set temperature to minimize the effect of cold storage (Qvist, 1979).

\section{Milk Coagulation}

Milks were adjusted to the required set temperature $\left(28,32\right.$, or $\left.36^{\circ} \mathrm{C}\right)$ and inoculated $(20 \mathrm{~g} / \mathrm{kg}$ of milk) with frozen pellets of Lactococcus lactis ssp. lactis/cremoris (DVS850, Chr. Hansen Inc., Milwaukee, WI). The starter culture was added approximately 10 min before adding rennet to minimize any $\mathrm{pH}$ decrease in the cheese vat before draining of whey, exploiting the long lag phase before exponential growth of frozen cultures (the normal ripening time allowed for frozen direct-tothe-vat cultures is $30-45 \mathrm{~min})$. Double-strength ( $\sim 650$ international milk-clotting units $/ \mathrm{mL}$ ) chymosin (Maxiren; DSM Food Specialties USA Inc., Eagleville, PA) was added at a rate of $57 \mu \mathrm{L} / \mathrm{kg}$ of milk. The rennet solution $(0.80 \mathrm{~mL})$ was diluted in $17 \mathrm{~mL}$ of water before addition, giving 37 international milk-clotting units $/ \mathrm{kg}$ of milk. For determining the time suitable for cutting of the coagulum, renneted milk was stirred for $1 \mathrm{~min}$ and an aliquot $(\sim 30 \mathrm{~mL})$ was removed for monitoring gel formation using rheometry, as described by Panthi et al. (2019).

\section{Curd Manufacture and Sampling}

The coagulated milk was cut based on the data from a rheometer when the storage modulus $\left(\mathrm{G}^{\prime}\right)$ reached approximately $35 \mathrm{~Pa}$ and was confirmed by visual observation. Cutting knives were fabricated to achieve curd cubes of 6,12 , or $18 \mathrm{~mm}$ (hereafter, "cube" is not mentioned before size). Coagula were cut in 3 dimensions within $1 \mathrm{~min}$, healed for approximately $3 \mathrm{~min}$, and gently stirred manually from 4 min after the start of cutting. For curds prepared from milks of 5 and $6 \%$ protein with 12 - and $18-\mathrm{mm}$ cut size, a total of $4 \mathrm{~kg}$ of UF permeate produced from the original milk was overlaid on the top of coagula before and after cutting to avoid curd damage during stirring. The temperature of the permeate was increased to the coagulation temperature before overlaying.

Starting from 5 min after cutting, curds were sampled every 10 min for moisture content. At 25 min after cutting, the curd and whey were heated to $37^{\circ} \mathrm{C}$ over 20 min, and this temperature was maintained and stirring continued. This gave a temperature increase of 9,4 , or $1^{\circ} \mathrm{C}$ for curds set at 28,32 , or $36^{\circ} \mathrm{C}$, respectively. At 75 min after cutting, $3 \mathrm{~kg}$ of whey was removed, $2 \mathrm{~kg}$ of water at $37^{\circ} \mathrm{C}$ was added to dilute the lactose content of whey, and curd stirring was continued until $115 \mathrm{~min}$ after cutting.

\section{Scanning and Transmission Electron Microscopy}

To investigate differences in curd microstructure, samples of curd were obtained from milk containing 4 and $6 \%$ protein and set at 28 or $36^{\circ} \mathrm{C}$ from coagula cut into 6-mm curd pieces. Curd samples were removed at 45 min after cutting and fixed in glutaraldehyde- 


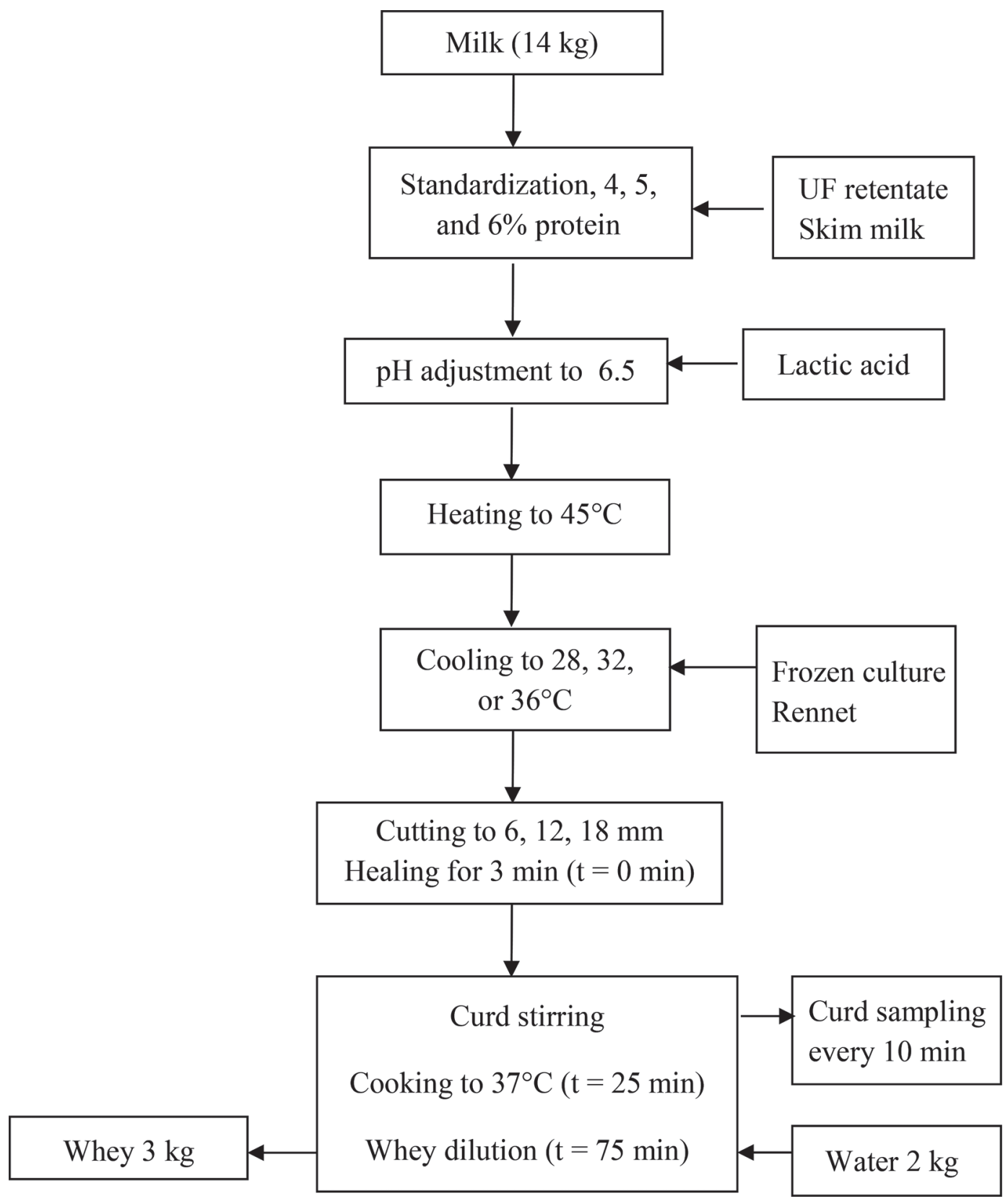

Figure 1. Schematic presentation of milk preparation and curd making.

formaldehyde for curd microstructure analysis using scanning electron microscopy and transmission electron microscopy as described by Panthi et al. (2019).

\section{Compositional Analysis}

Composition of milk, permeate, retentate, and skim milk was determined with a Fourier-transform infra- red spectroscopy milk analyzer (Bentley Instruments Inc., Chaska, MN). Mineral contents of milk were determined using inductively coupled plasma optical emission spectrometry (Thermo iCAP 6300, Thermo Fisher Scientific, Waltham, MA) after wet digestion as described by Gavlak et al. (2005). Curd moisture contents were determined in triplicate using a hot air oven method as described by Mateo et al. (2009a). 
Relative curd moisture (RCM) content was calculated as described by Panthi et al. (2018), and RCM data were fitted to the following empirical equation:

$$
\mathrm{RCM}=\mathrm{RCM}_{o}-\frac{\left(\text { time }^{k}+a\right)}{k},
$$

where $\mathrm{RCM}_{o}$ is relative curd moisture content at time $0=100, k$ is the kinetic constant, and $a$ is another constant factor in the model. Values of $k, a$, and the coefficient of determination $\left(\mathrm{R}^{2}\right)$ were calculated.

\section{Statistical Analysis and Experimental Design}

Milk composition was analyzed using 1-way ANOVA with Tukey honest significance difference for comparing means using SPSS Statistics (version 24; IBM, Armonk, $\mathrm{NY}$ ) at a 95\% significance level. Curd moisture loss kinetics data obtained from Equation 1 were analyzed using nonlinear least squares (nls) function and plotted using the ggplot2 package in the $\mathrm{R}$ studio (version. 1.1.383) of the $\mathrm{R}$ program (version 3.4.2, R Foundation for Statistical Computing, Vienna, Austria).

Influence of protein concentration, set temperature, and curd size was analyzed using response surface methodology with a central composite design $(\alpha=1)$ as shown in Table 1. Temperature and protein levels were randomized, and batches with similar cut size were prepared on each day for consecutive runs. Initial trials were carried out to examine the process variation within trials (data were excluded from analysis), and then 21 cheesemaking trials were conducted for data analysis. The full polynomial model (Equation 2) was used to determine the relationship between 3 variables on curd moisture:

$$
Y=b_{o}+\sum_{i=1}^{3} b_{i} X_{i}+\sum_{i=1}^{3} b_{i i} X_{i}^{2}+\sum_{i=1}^{3} \sum_{j=i+1}^{3} b_{i j} X_{i} X_{j},
$$

where $Y$ is the response variable, $b_{o}$ is a model intercept, and $X_{i}$ and $X_{j}$ are the factor levels. The model comprises linear $\left(b_{i}\right)$, quadratic $\left(b_{i i}\right)$, and cross-product $\left(b_{i j}\right)$ terms. Response surface modeling was carried out using PROC RSREG in SAS/STAT (version 14.3; SAS Institute Inc., Cary, NC). Cross-product terms were removed from the full model for model parameter estimate. The same reduced model was used to create contour plots using PROC REG and PROC TEMPLATE in SAS and surface plots using Design Expert (version 10, Stat-Ease Inc., Minneapolis, MN).

\section{RESULTS AND DISCUSSION}

\section{Composition of Milk}

The standardized milk compositions before cheesemaking are shown in Table 2. As expected, protein, fat, and TS contents increased significantly $(P<0.05)$ with increased protein concentration in the standardized milk, with a uniform protein-to-fat ratio (Table 2). Similarly, $\mathrm{pH}$ and lactose levels were not significantly affected. The levels of total calcium and phosphate increased significantly with increasing protein levels. Sandra et al. (2011) also reported a significant increase of total calcium in protein concentrated milk. Because one-third of calcium in milk is contained in the serum phase, a portion of this soluble calcium passes into permeate during UF. Hence, the calcium-to-protein ratio decreased with increasing protein content.

\section{Curd Breakage During Stirring}

There was a significant interactive effect of set temperature and protein level $(P=0.015$; Supplemental Table S1; https://doi.org/10.3168/jds.2018-15051) on the time from renneting of milk to when the coagula was cut. Set to cut time was shorter with higher set temperature and protein levels. Thus, cutting was performed at a storage modulus of approximately $35 \mathrm{~Pa}$ rather than at a specified time to obtain uniform curd rigidity.

During initial stirring after cutting, breakage of curds occurred due to resistance of the curd movement, when permeate was not overlaid. Breakage of curds can be

Table 1. Variable factors and conditions used in the response surface design

\begin{tabular}{llllrrrr}
\hline & \multicolumn{3}{c}{ Symbol } & & \multicolumn{3}{c}{ Level } \\
\cline { 2 - 3 } \cline { 5 - 7 } Condition & Code & Unit & & & \multicolumn{1}{c}{0} & +1 \\
\hline Temperature & $\mathrm{X} 1$ & & & 28 & 32 & 36 \\
Cut size & $\mathrm{X} 2$ & $\mathrm{~mm}^{3}$ & & 6 & 12 & 18 \\
Protein & $\mathrm{X} 3$ & $\%(\mathrm{~g} / 100 \mathrm{~g})$ & & 4 & 5 & 6 \\
\hline
\end{tabular}


Table 2. Composition of standardized milk before cheesemaking

\begin{tabular}{lccc}
\hline & \multicolumn{3}{c}{ Milk composition } \\
\cline { 2 - 4 } Component & $\begin{array}{c}4 \% \text { Protein } \\
(\mathrm{n}=6)\end{array}$ & $\begin{array}{c}5 \% \text { Protein } \\
(\mathrm{n}=7)\end{array}$ & $\begin{array}{c}6 \% \text { Protein } \\
(\mathrm{n}=8)\end{array}$ \\
\hline Protein $(\mathrm{g} / 100 \mathrm{~g})$ & $3.94^{\mathrm{c}}$ & $5.03^{\mathrm{b}}$ & $6.02^{\mathrm{a}}$ \\
Fat $(\mathrm{g} / 100 \mathrm{~g})$ & $3.95^{\mathrm{c}}$ & $5.04^{\mathrm{b}}$ & $6.05^{\mathrm{a}}$ \\
Protein-to-fat ratio & $1.00^{\mathrm{a}}$ & $1.00^{\mathrm{a}}$ & $0.99^{\mathrm{a}}$ \\
Lactose $(\mathrm{g} / 100 \mathrm{~g})$ & $4.76^{\mathrm{a}}$ & $4.60^{\mathrm{a}}$ & $5.02^{\mathrm{a}}$ \\
TS $(\mathrm{g} / 100 \mathrm{~g})$ & $13.52^{\mathrm{c}}$ & $15.66^{\mathrm{b}}$ & $17.43^{\mathrm{a}}$ \\
Total calcium $(\mathrm{g} / \mathrm{kg})$ & $1.33^{\mathrm{c}}$ & $1.60^{\mathrm{b}}$ & $1.93^{\mathrm{a}}$ \\
Total phosphate $(\mathrm{g} / \mathrm{kg})$ & $2.96^{\mathrm{c}}$ & $3.60^{\mathrm{b}}$ & $4.24^{\mathrm{a}}$ \\
Ca/protein $(\mathrm{mg} / \mathrm{g})$ & $33.6^{\mathrm{a}}$ & $31.7^{\mathrm{b}}$ & $32.05^{\mathrm{b}}$ \\
$\mathrm{pH}$ & $6.75^{\mathrm{a}}$ & $6.74^{\mathrm{a}}$ & $6.76^{\mathrm{a}}$ \\
\hline
\end{tabular}

${ }^{\mathrm{a}-c}$ Means within a row with the same superscript were not different $(\alpha=0.05)$.

illustrated by contour plots of curd moisture content over stirring (Supplemental Figure S1A-D; https://doi .org/10.3168/jds.2018-15051). After 5 min of stirring, when the cut size used was increased from 6 to $12 \mathrm{~mm}$, curds were observed to contain a greater moisture for all 4,5 , or $6 \%$ protein curds, whereas such a trend in curd moisture content was not observed when using the cut size from 12 to $18 \mathrm{~mm}$, indicating breakage of curd at the large cut size. At 25 min of stirring, the effect of changing cut size was evident for curds of $4 \%$ protein as indicated by a greater curd moisture content with higher cut size from 6 to $18 \mathrm{~mm}$. However, applying the same change in cut size with curds of $6 \%$ protein resulted in similar moisture contents $(\sim 72 \%)$. As the stirring continued to 45 to $115 \mathrm{~min}$, the effect of changing cut size was evident for $4 \%$ protein milk, whereas the moisture content of curds with $5 \%$ protein was observed to be less influenced when using cut size from 12 to $18 \mathrm{~mm}$, and for $6 \%$ protein the effect of changing cut size on curd moisture was negligible. Therefore, curds with 12 - or $18-\mathrm{mm}$ cut size and 5 or $6 \%$ protein were highly affected by the breakage of curds.

Curds require whey to float during stirring so that curd can move along with the motion of stirrer. However, slow release of whey from the curds from 5 or $6 \%$ protein with cut at a large size did not allow curd to move during initial stirring, which subsequently led to the breakage of curds into small particles. Maintaining the curd size during stirring was considered important in this study to establish the relationship between cut size and other variables. To avoid breakage of curds, a layer of UF permeate was overlaid on the coagula before and after cutting $(2 \mathrm{~kg}+2 \mathrm{~kg})$ for trials conducted with milk with 5 and $6 \%$ protein and using a cut size of 12 and $18 \mathrm{~mm}$. Overlaying permeate allowed the movement of curds during initial stirring and increased curd interparticle distance, which resulted in the curds maintaining their shape and size. As expected, permeate-overlaid curds had a higher moisture content compared with those prepared without overlay because of the retention in size (Supplemental Figure S2; https: //doi.org/10.3168/jds.2018-15051). Hence, overlaying of permeate during cutting helped to establish the relationship of cut size with other variables.

\section{Curd Moisture Loss During Stirring}

Curd moisture contents during stirring from 5 to 115 min decreased under each experimental condition (Figure 2). Interestingly, the decrease in moisture content in curds of $6-\mathrm{mm}$ cut size showed a logarithmic trend, whereas the decrease in curds of 12 - or $18-\mathrm{mm}$ cut size was linear. Evidently, the profile of moisture loss from curds set at $28^{\circ} \mathrm{C}$ with cut size $6 \mathrm{~mm}$ was slightly different from logarithmic due to a faster decrease in curd moisture content during cooking (25-45 min of stirring). Such a rapid decrease in moisture content loss was due to greater increase in temperature during cooking. However, a fast decrease in moisture even for curds set at $28^{\circ} \mathrm{C}$ and cut at larger cut size (12 or $18 \mathrm{~mm}$ ) was less evident. Probably, the contraction of the curds occurs at the curd surface and the presence of a larger proportion of moisture in the internal curd matrix minimizes the magnitude of moisture loss by temperature increase. Interestingly, the rate of moisture loss after $45 \mathrm{~min}$ of stirring showed a linear trend in each condition.

It is apparent that curd from milk with a higher protein concentration attained lower moisture content at a given time compared with the curd from milk with a lower protein content. However, the rate of moisture loss was not influenced by protein concentration, as indicated by a similar slope of the moisture loss curve at similar conditions of set temperature and cut size (Figure 2). This finding is consistent with the results of Peri et al. (1985), who reported that expulsion of whey 
from curd was independent of protein concentration in milk, which was investigated within approximately $5 \times$ protein concentration of milk. The results from the present study also agree with the findings of Thomann et al. (2008), who observed greater volume of total liquid collected when combining permeate release during membrane filtration and expelled whey during curd stirring from concentrated curd compared with total whey expelled from regular milk.

\section{Prediction of Curd Moisture}

Prediction of in-vat curd moisture content using an empirical model is currently of interest (Panthi et al., 2018). The present study demonstrates various profiles of curd moisture loss depending on curd size and set temperature, emphasizing the requirement of a model that can explain the curd moisture loss under variable conditions. The RCM data were fitted to Equation 1; however, this poorly explained the curd moisture data from the curd cut at $18 \mathrm{~mm}$ at $28^{\circ} \mathrm{C}$ or $32^{\circ} \mathrm{C}\left(\mathrm{R}^{2}\right.$
$=0.79-0.88)$. There was a better fit with data from curds set at $36^{\circ} \mathrm{C}\left(\mathrm{R}^{2}=0.90\right)$, probably due to there being only a $1^{\circ} \mathrm{C}$ increase during cooking, resulting in an almost constant temperature during stirring. A representative graph of the model fit on RCM data is presented in Figure 3. The model explained the moisture loss profile of curds at small and large cut sizes, with $\mathrm{R}^{2}$ values being 0.98 and 0.90 , respectively. As expected, curds coagulated at $36^{\circ} \mathrm{C}$ with $4 \%$ protein and cut at $6 \mathrm{~mm}$ had faster moisture loss kinetics $(\mathrm{k}=$ $0.51)$ compared with those cut at $18 \mathrm{~mm}(\mathrm{k}=0.30)$. Curds of small particle size have a larger surface area and a shorter distance from center to edge for whey movement compared with bigger curd particles, which have a much smaller surface-to-volume ratio, resulting in restricted whey expulsion and subsequent greater retention of moisture (Renault et al., 1997; Dejmek and Walstra, 2004).

In this study, curd size was varied based on spacing between the curd knives. Alternatively, curd size can be varied depending on the number of rotations of the
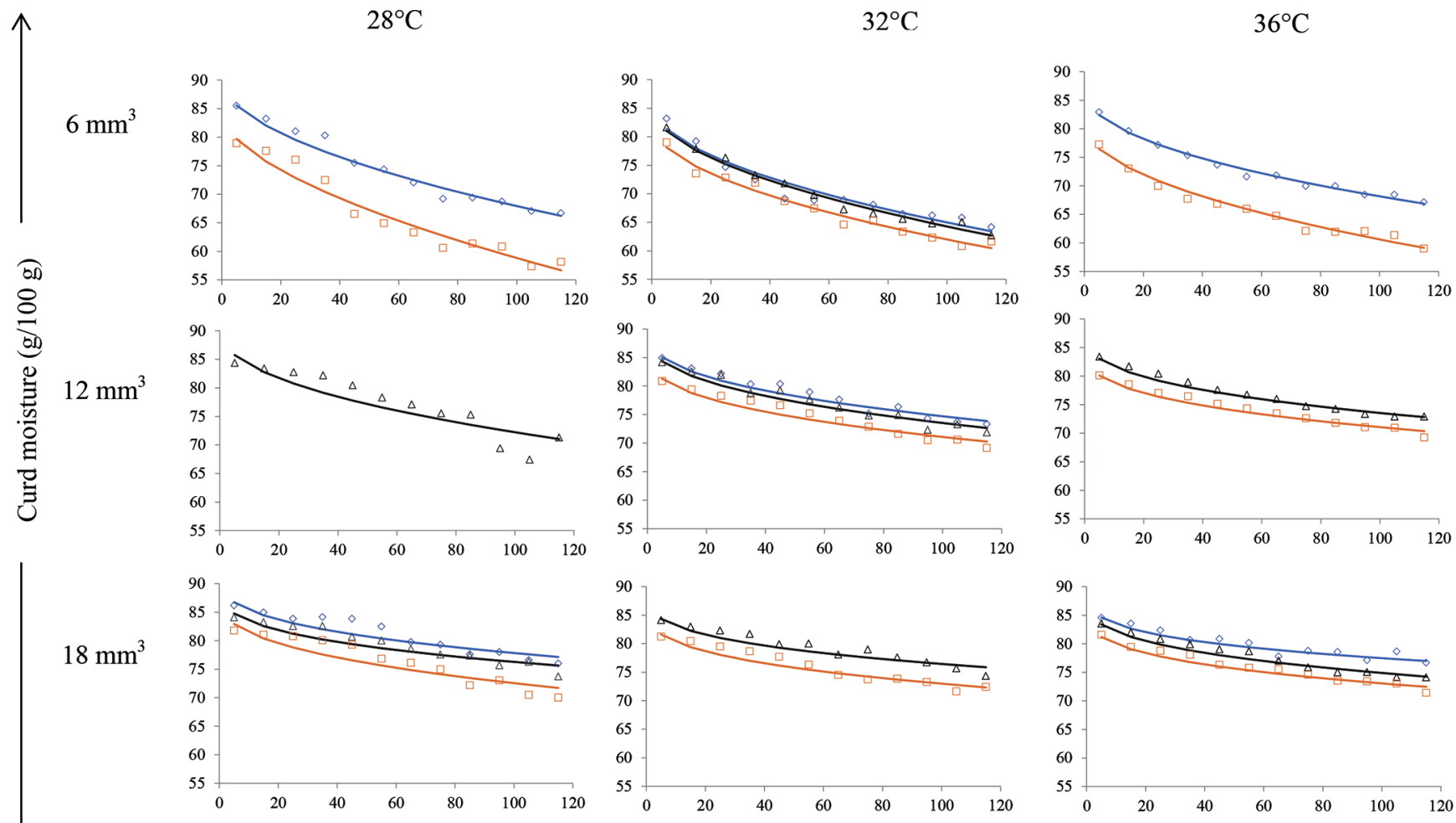

Stirring time (min)

Figure 2. Moisture loss profile of curds ( $/ 100 \mathrm{~g}$ ) during stirring from 5 to $115 \mathrm{~min}$ after cutting at various conditions of set temperature $\left(28-36^{\circ} \mathrm{C}\right)$, cut size $\left(6-18 \mathrm{~mm}^{3}\right)$, and protein concentration $(\diamond=4 \%, \Delta=5 \%, \square=6 \%)$. Trend lines were drawn using Equation 1 for actual curd moisture content. Permeate was overlaid during cutting for coagulum of 5 and $6 \%$ protein with 12 - and 18 -mm cut size. 


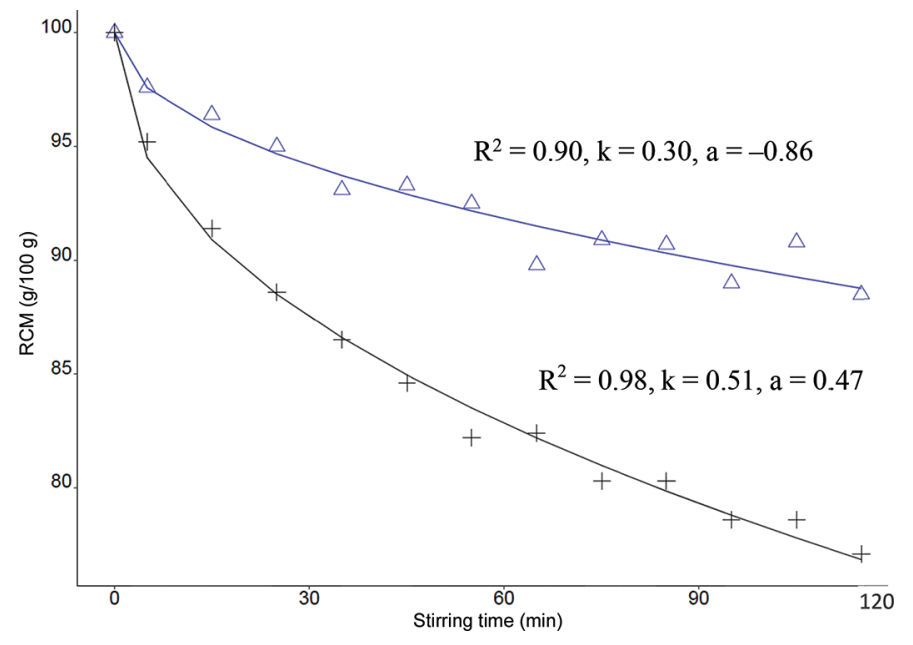

Figure 3. Representative plot of model fitted to the relative curd moisture (RCM) data as a function of time during stirring. $+=36^{\circ} \mathrm{C}$, $6 \mathrm{~mm}, 4 \%$ protein; $\Delta=36^{\circ} \mathrm{C}, 18 \mathrm{~mm}$, and $4 \%$ protein. Coefficient of determination $\left(\mathrm{R}^{2}\right)$ and model parameters constants $(\mathrm{k}$ and a) are the values calculated using the model. The line indicates model prediction.

blades through the coagulum during cutting; knives are of fixed dimensions, which results in a wide range of curd size (Johnston et al., 1998; Everard et al., 2008; Mateo et al., 2009b). Although actual whey expulsion rates may vary based on the method of cutting (especially when curd particles are cut into irregular shapes), in general the same principles apply in that overall moisture loss from the curd will be influenced by the size range of the curd particles.

\section{Response Surface Modeling of Curd Moisture During Curd Stirring}

The ANOVA of the regression model fit showed that most variations in curd moisture were explained by the linear and quadratic regression terms of the model, whereas cross-product terms were nonsignificant (Table 3). To estimate the regression coefficients of the polynomial regression model, a response surface model without cross-product terms was used so that estimates could be more robust and more precise. Table 4 summarizes estimates and goodness of model fit $\left(\mathrm{R}^{2}\right.$ and coefficient of variation) of the reduced model, which was satisfactory for prediction of curd moisture at a given stirring time.

Coagulation temperature (X1) had a significant negative effect on curd moisture for the first $45 \mathrm{~min}$, but not after the curd temperature reached $37^{\circ} \mathrm{C}$ (i.e., by the end of cooking; with the exception of $105 \mathrm{~min}$ ). Cut size (X2) had a significant positive effect on curd moisture at all times, and this effect increased over stirring time, as indicated by increasing values of the coefficient for cut size (Table 4). The negative effect of protein concentration (X3) on curd moisture content was fairly uniform during stirring, indicating that protein concentration did not markedly influence the curd moisture loss. The significant quadratic effect of cut size (X2) indicates a nonlinear correlation between cut size and curd moisture content.

\section{Curd Moisture Loss During Cutting and Cooking}

The effects of set temperature, cut size, and protein content on the relative rate of initial curd moisture loss (during the first 5 min after cutting) compared with the phase of increasing temperature (25-min after cutting) are shown in Figure 4. The contour plots show that the rate of moisture loss follows different patterns depending on whether it is measured during the initial stirring or during cooking. As expected, the initial rate of moisture loss was proportional to the coagulation temperature and the rate of moisture loss during cooking was proportional to the temperature gradient (Figure 4A, B). In both phases, the rate of moisture loss was inversely correlated with curd cut size. The contour plot shows that when setting milk at lower temperatures, coagulum should be cut to smaller sizes to achieve similar rates of initial moisture loss than under conditions where milk is set at normal temperatures (Figure 4A). Curd cut at larger cut size (12-18 mm) had almost negligible moisture loss during initial stirring. The slow release of moisture in particles of larger cut size during initial stirring causes breakage because the expulsion of whey allows curd to move and float during stirring. The slow release of whey from a curd at lower temperature can be compensated by reducing the coagulum cut size.

In contrast, for curds set at lower temperature (especially with smaller cut size), the rate of moisture loss during cooking was $0.32 \% / \mathrm{min}$ and then decreased with increasing temperature or cut size to $0.07 \%$ / min for larger curds set at higher temperature. This occurred because the increase in temperature during cooking to $37^{\circ} \mathrm{C}$ was larger when the set temperature was $28^{\circ} \mathrm{C}$ compared with a set temperature of $36^{\circ} \mathrm{C}$. At higher temperature, greater rearrangement of casein micelles in the protein network occurs, creating a force for curd contraction (Mellema et al., 2002). Subjecting the curd to a temperature increase enhances contraction of the protein network, which causes concomitant whey expulsion. This perhaps minimized the effect of set temperatures on curd moisture content after cooking (Table 3). However, Fagan et al. (2007) observed a significant effect of coagulation temperature on curd 

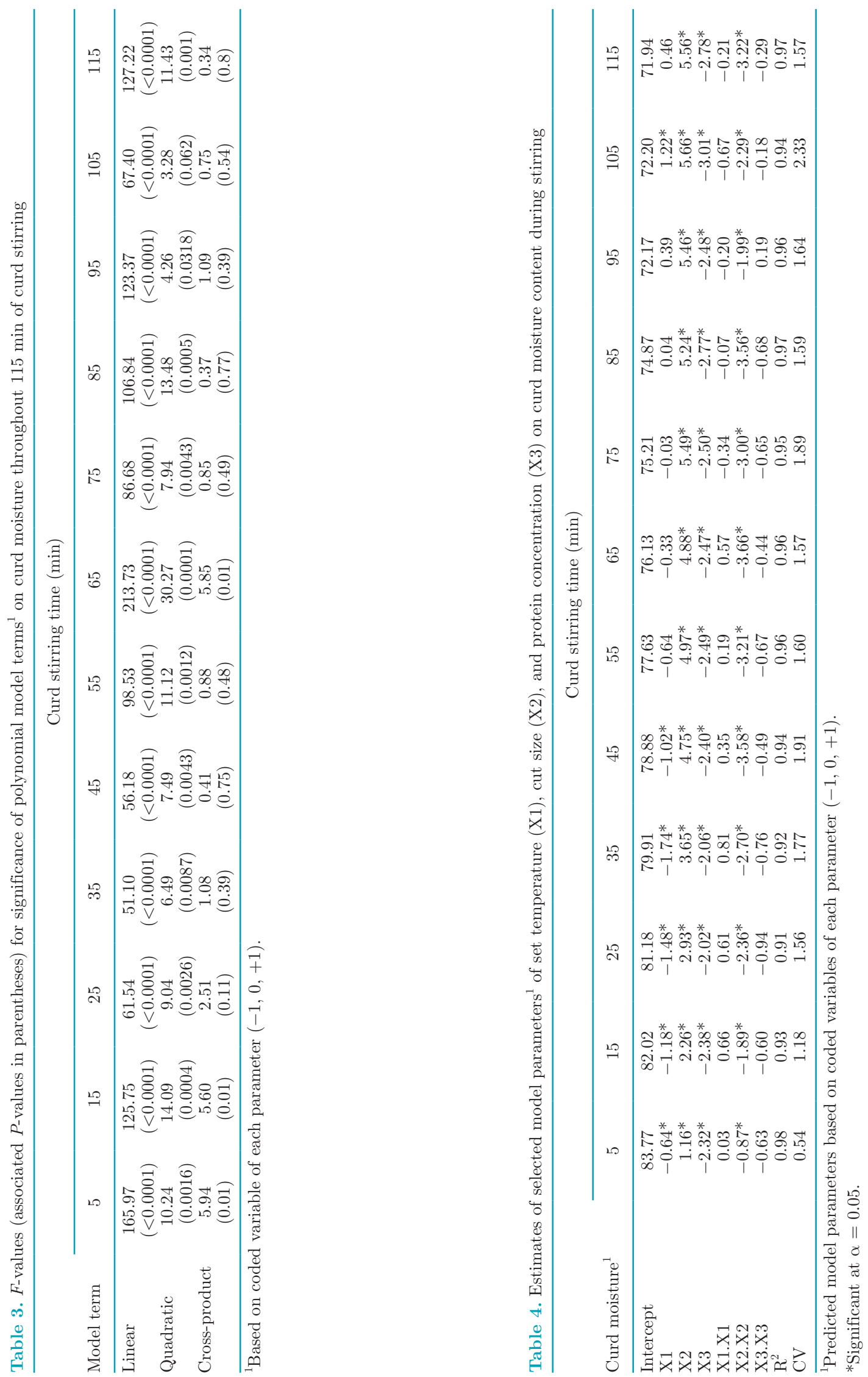
moisture content during stirring (5-65 min) when cooking of curds was not undertaken.

In the present study, the effect of $\mathrm{pH}$ change was minimized by adding lactic acid and frozen culture and subsequently giving a shorter ripening time $(\sim 10 \mathrm{~min})$ than in standard cheesemaking practice $(\sim 45 \mathrm{~min})$. The $\mathrm{pH}$ value of whey samples measured after $75 \mathrm{~min}$ of stirring was not significantly influenced $(P=0.426)$ by protein concentration; however, set temperature did significantly influence $\mathrm{pH}(P=0.031)$. The average $\mathrm{pH}$ of whey samples measured after 75 min was $6.31,6.34$, and 6.36 from the curds coagulated at 28,32 , and $36^{\circ} \mathrm{C}$, respectively. Slight differences in the $\mathrm{pH}$ at $75 \mathrm{~min}$ suggest that $\mathrm{pH}$ differences during the early stages of stirring, for example at $45 \mathrm{~min}$, could be negligible. It is suggested that little $\mathrm{pH}$ change is observed in the early stages of industrial-scale cheesemaking with the growing use of direct-vat inoculum cultures, as was observed in the present study. However, changes in $\mathrm{pH}$ in the early stages may be more evident when bulk cultures are used, promoting earlier curd syneresis.

\section{Curd Moisture Content at 75 min}

Curd moisture contents at $75 \mathrm{~min}$ as influenced by cut size and protein concentration are presented in Figure $5 \mathrm{~A}$. It is evident that on increasing protein concentration of milk, moisture content of the curds decreased and curd moisture content increased with increasing coagulum cut size. Similar trends in the contour plots were observed at each sampling point with reduced curd moisture contents over time (plots not shown).
Whey drainage occurs at approximately 75 min after cutting for many semihard cheese manufacturing processes. It is apparent that, at $75 \mathrm{~min}$, cheese curds produced with a 6 -mm cut size and from milk of $6 \%$ protein attained a low curd moisture content $(60 \mathrm{~g} / 100$ $\mathrm{g}$ of curds), whereas curds of $4 \%$ protein and with an $18-\mathrm{mm}$ cut size retained significantly more moisture (79 g/100 g of curds). These results demonstrate that in-vat curd moisture content varies widely with respect to cut size and protein level in milk. It is proposed that these 2 factors can be exploited to control the moisture content of curds during stirring. For example, curds with $72 \%$ moisture can be produced with milk concentrated to $4 \%$ protein with a cut size of less than $7 \mathrm{~mm}$, whereas at a milk protein concentration of $6 \%$, a cut size of approximately $12 \mathrm{~mm}$ is required to obtain a similar moisture level. Therefore, manufacturing cheese from milk with increased protein concentrations requires increased curd sizes to achieve similar moisture to that in standard cheese manufacturing practices. Thus, cheesemaking from milk with increased protein concentration requires modified standard operating procedures to maintain an appropriate stirring time between cutting of the curd and curd drainage.

Achieving uniform curd moisture content before drainage of curds is a key control point for consistency in the cheesemaking process. To explore curd moisture content over stirring, response surface contour plots were generated with stirring time as a factor. For example, when cut size is fixed to $12 \mathrm{~mm}$ at a set temperature $32^{\circ} \mathrm{C}$, it will take $95 \mathrm{~min}$ to attain $74 \%$ moisture for curds from $4 \%$ protein milk, which is re-
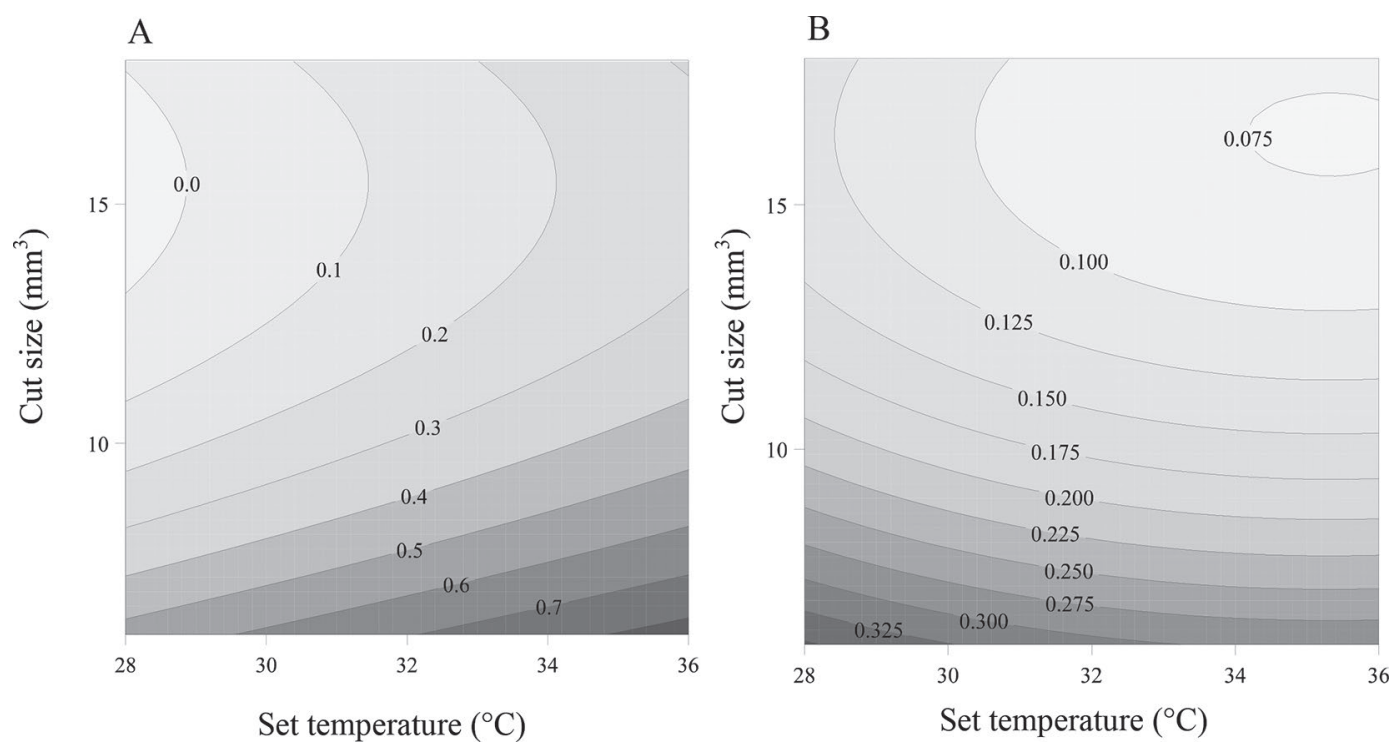

Figure 4. Contour plots of relative curd moisture loss (\%/min) (A) after initial stirring and (B) during cooking as affected by set temperature and cut size. Permeate was overlaid during cutting for coagula of 5 and $6 \%$ protein with 12 - and 18 -mm cut size. 
duced to 75 min for curds from $5 \%$ protein milk and 45 min for curds from $6 \%$ protein milk (Figure 5C). Likewise, curds with $70 \%$ moisture can be produced in 55 min when cutting a coagulum with 6 -mm cut size, and more than 115 min is required to achieve a similar

A

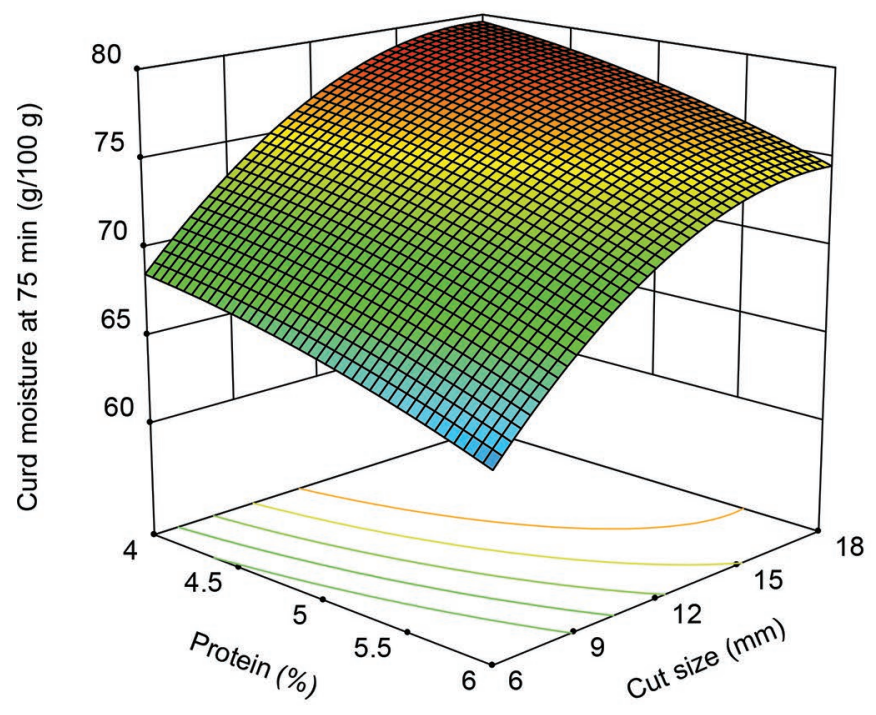

C

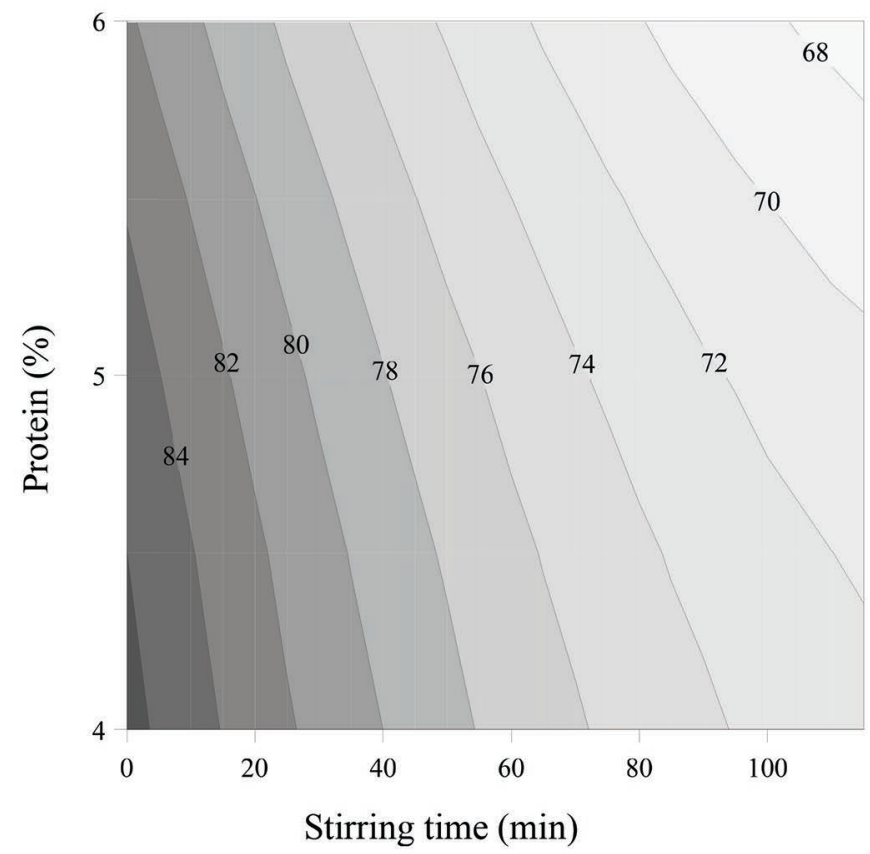

level of curd moisture when cut size is increased to 12 mm (Figure 5D). Therefore, concentrating milk protein levels allows processing of increased milk volume and a shorter processing time, thus increasing efficiency in 2 ways.
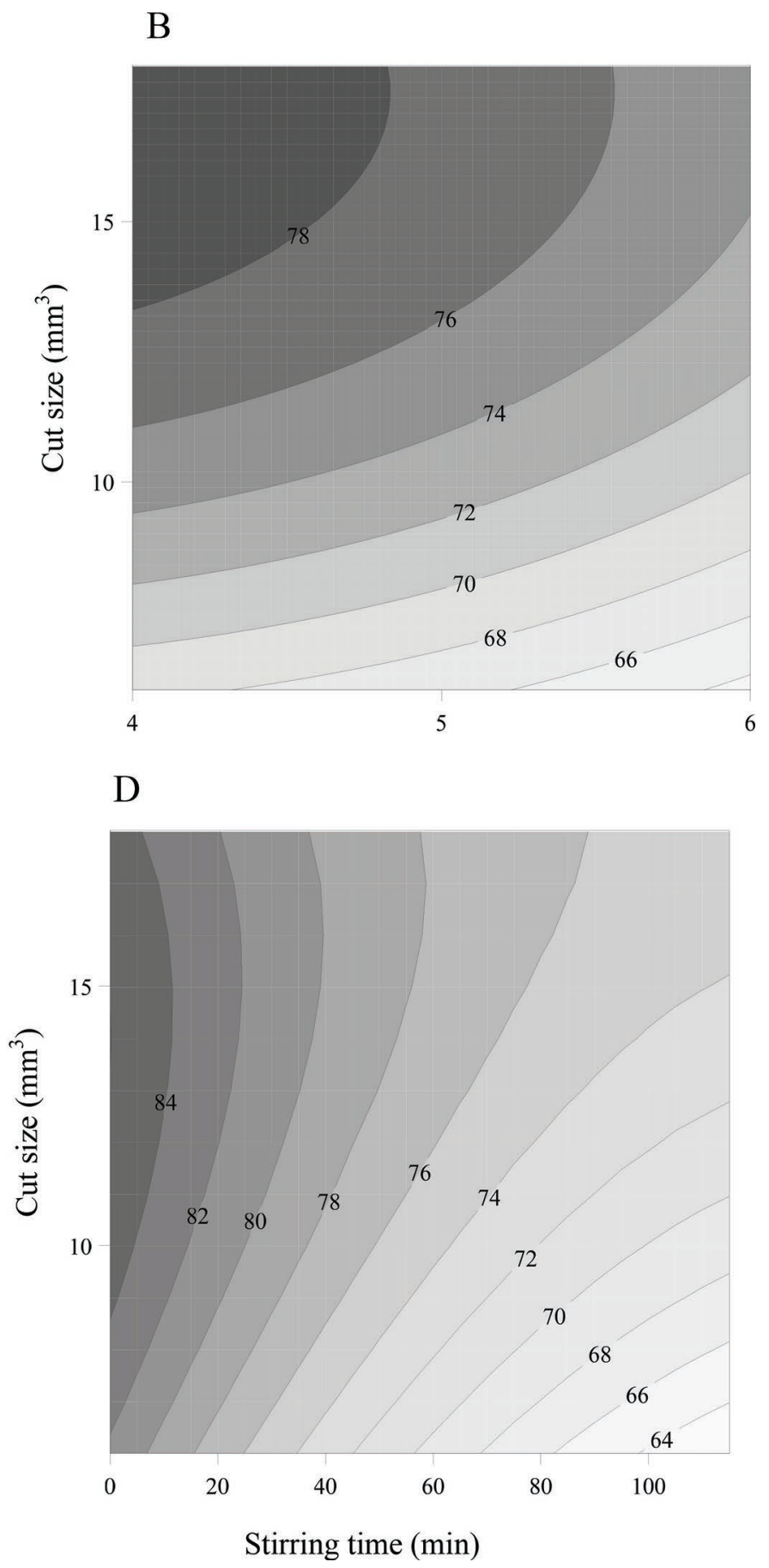

Figure 5. (A) Surface plots and (B) contour plot of curd moisture content (g/100 g) as affected by protein level and cut size at 75 min of stirring. Contour plot of curd moisture content as a function of stirring time as influenced by (C) protein level and (D) cut sizes. Permeate was overlaid during cutting for coagula of 5 and $6 \%$ protein with 12 - and $18-\mathrm{mm}$ cut size. 
Previous studies have shown that cheese moisture content decreases when increasing protein levels to approximately 4.5\% (Guinee et al., 1996, 2006; Broome et al., 1998), which could be because of lower curd moisture content before drainage. The negative correlation of moisture content with protein level can be explained partly by an increased level of protein and fat in standardized milk due to the loss of serum phase by concentration (Thomann et al., 2008). Furthermore, increasing the volume fraction of the curd particles with respect to the serum phase leads to a subsequent increase in the frequency of collisions between curd particles, contributing to greater moisture loss during stirring due to particle deformation (Guinee et al., 2006; Geng et al., 2011). Permeate overlay in the present study was expected to minimize such influences.

Some studies have suggested a decrease in syneresis rate (Calvo and Espinoza, 1999; Caron et al., 2001; Thomann et al., 2008) with increasing milk concentration ratio, whereas other studies that expressed syneresis in terms of moisture retention reported increased syneresis rate with increasing protein levels in milk (Casiraghi et al., 1987). The results of the present study confirmed that curd moisture loss in-vat was independent of protein concentration of milk and that the observed differences in curd moisture content were mainly attributed to differences in milk solid contents. This probably results in curds from concentrated milk expelling a lower weight of whey compared with those prepared from regular milk, as moisture constitutes a smaller proportion of weight of curds from concentrated milks compared with those from unconcentrated milk at any given time during stirring (Casiraghi et al., 1987; Thomann et al., 2008).

\section{Curd Microstructure}

Scanning Electron Microscopy. Curd microstructure, as influenced by coagulation temperature, is shown in Figure 6 for milk with $6 \%$ protein concentration and set at either 28 or $36^{\circ} \mathrm{C}$. At low magnification, curd particles at both temperatures appeared to have a loose structure with many larger voids (Figure 6A and B). Differences in the microstructure of curds were more apparent at higher magnification, with the casein particles showing a higher degree of fusion in curds set at $36^{\circ} \mathrm{C}$ (Figure $6 \mathrm{~F}$ ), which resulted in slightly thicker strands and a flattened shape compared with the curd formed at $28^{\circ} \mathrm{C}$ (Figure 6E). Similar differences were observed at the time of cutting the coagulum (Panthi et al., 2019), but casein micelles were fused to a greater extent in the cooked curds in both treatments. For milk containing $3.3 \%$ protein, Ong et al. (2011) also observed a fine regular protein network in curds that had been set at $27^{\circ} \mathrm{C}$ and subsequently cooked to $38^{\circ} \mathrm{C}$ compared with curds set at $36^{\circ} \mathrm{C}$ and cooked to $38^{\circ} \mathrm{C}$; the latter conditions resulted in a dense protein network with larger casein micelles aggregates.

Transmission Electron Microscopy. Figure 7 shows transmission electron micrographs of curds from different treatments. At low magnification it could be seen that casein micelles formed a regular network with fat globules interspersed in the curds when set at $28^{\circ} \mathrm{C}$ (Figure $7 \mathrm{~A}$ ) or $36^{\circ} \mathrm{C}$ (Figure 7B), but the network appeared greatly condensed with more connection points at $36^{\circ} \mathrm{C}$. Medium- and high-magnification images showed that casein micelles were fused to thicker branches in the curds set at $36^{\circ} \mathrm{C}$ (Figure 7D and F) compared with those set at $28^{\circ} \mathrm{C}$ (Figure $7 \mathrm{C}$ and $\mathrm{E}$ ). This correlates well with the scanning electron microscopy findings. Changes in the curd microstructure during cooking were greater for curds set at $28^{\circ} \mathrm{C}$ compared with $36^{\circ} \mathrm{C}$. Curds set at $28^{\circ} \mathrm{C}$ had a loose and compact structure of casein micelles aggregates before cooking (Panthi et al., 2019), which, after cooking, appeared to have a porous structure with extensively fused casein micelles in an aggregate. Ong et al. (2013) reported no difference in the microstructure of cooked curds prepared from milk with increasing protein levels $(4-5.8 \%)$ coagulated at $33^{\circ} \mathrm{C}$. Thus, it appears that the temperature at which coagulation occurs has a greater influence on internal structure than protein concentration.

Curds set at $28^{\circ} \mathrm{C}$ probably had continuous casein micelle rearrangement during cooking because of less cross-linking of casein micelle aggregates (Figure 6E), whereas in curds set at $36^{\circ} \mathrm{C}$, such phenomena probably occurred before cooking as observed by flattened and fused casein micelle aggregates (Figure 6F). Void spaces (probably filled with whey) observed in Figure $6 \mathrm{~A}$ and $\mathrm{B}$ with curds set at 28 or $36^{\circ} \mathrm{C}$ are probably due to rearrangement of casein micelles in the protein network (containing whey and fat globules before scanning electron microscopy sample preparation) that exerted more pressure for whey, leading to accumulation of whey between casein clusters (Van Vliet et al., 1991). For curds set at $28^{\circ} \mathrm{C}$, larger void spaces were observed after cooking compared with at the time of cutting (Panthi et al., 2019), indicating that protein network rearrangement was greater during cooking for curds set at $28^{\circ} \mathrm{C}$ compared with curds set at $36^{\circ} \mathrm{C}$. This probably explains the greater moisture loss during cooking from curds set at $28^{\circ} \mathrm{C}$ compared with those set at $36^{\circ} \mathrm{C}$.

\section{CONCLUSIONS}

Interactive effects of milk protein concentration, cut size, and coagulation temperature on curd moisture 

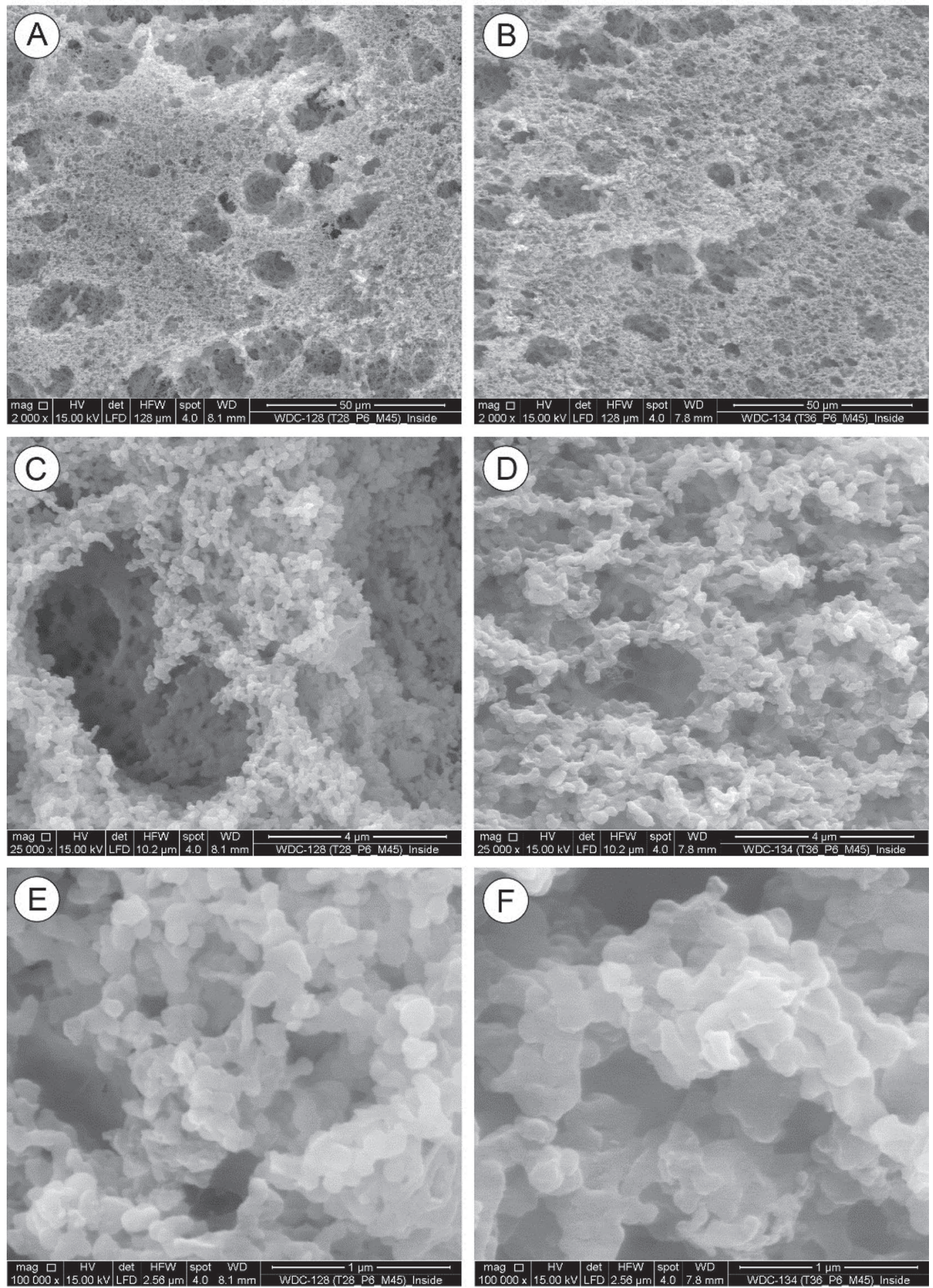

Figure 6. Representative scanning electron micrographs of cooked curd particles made from $6 \%$ protein-standardized milk that were renneted at 2 set temperatures $\left(\mathrm{A}, \mathrm{C}, \mathrm{E}: 28^{\circ} \mathrm{C} ; \mathrm{B}, \mathrm{D}, \mathrm{F}: 36^{\circ} \mathrm{C}\right)$. Micrographs were taken at a distance of approximately $500 \mu \mathrm{m}$ from the outside of the particle. 
loss property were presented. The trend for moisture loss from curd cubes of $6 \mathrm{~mm}$ was logarithmic, whereas moisture loss for larger curds was of a linear pattern. Curds set at lower temperature released less moisture immediately after cutting, which can be accelerated by reducing the cut size. Response surface modeling showed that cut size and protein levels were the most important factors influencing moisture content during stirring, whereas coagulation temperature did not have a significant influence, particularly after cooking (heating to $37^{\circ} \mathrm{C}$ ). When protein concentration in the milk was increased, excessive curd breakage occurred when a large cut size $(12-18 \mathrm{~mm})$ was used. This suggested that cutting to smaller cut sizes would be required for cutting the coagulum from protein-concentrated milk.
It was shown that overlaying permeate on the coagula from protein-concentrated milk will prevent breakage of some curds. However, further research is required to investigate the effect of the application of permeate on coagula on cheese quality and composition in an industrial cheese manufacturing process. This study shows that if the cut size cannot be increased during cheesemaking with milk of increased protein level, it is necessary to shorten the vat residence time before draining the whey. The microstructure of the cheese curd after cooking (as shown using both transmission and scanning electron microscopy) retained the differences initiated by coagulating the milk at different temperatures, with curd set at $36^{\circ} \mathrm{C}$ having thicker protein network strands with more fusion of casein
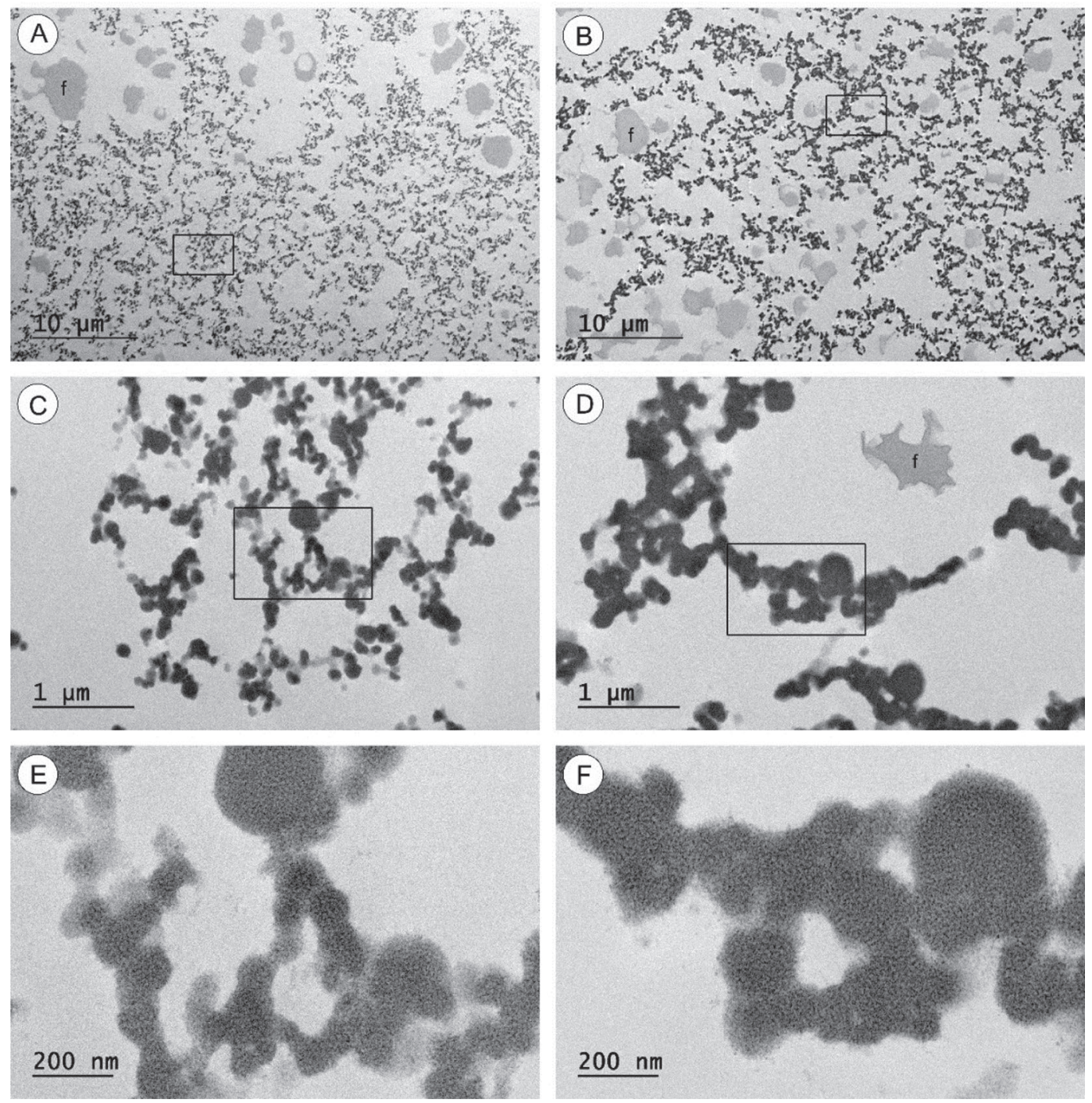

Figure 7. Internal microstructure of cooked curd particles manufactured with $6 \%$ protein-standardized milk renneted at different set temperatures (A, C, E: $28^{\circ} \mathrm{C} ; \mathrm{B}, \mathrm{D}, \mathrm{F}: 36^{\circ} \mathrm{C}$ ) as analyzed by transmission electron microscopy. Micrographs were taken at a distance of approximately 500 to $600 \mu \mathrm{m}$ from the outside of the particle. Boxed areas are shown in increasing magnifications. $\mathrm{f}=$ fat globules. 
particles compared with curd coagulated at $28^{\circ} \mathrm{C}$. A fundamental understanding of curd moisture loss properties as influenced by cut size, protein concentration, and coagulation temperature gained from this research can be applied in the cheesemaking process to predict curd moisture content from protein-standardized milk, reduce the effect of seasonal variability in milk composition, and increase the process efficiency.

\section{ACKNOWLEDGMENTS}

The authors acknowledge the Dairy Levy Trust Fund administered by Dairy Research Ireland and Utah Agriculture Experiment Station, Utah State University (Logan), for providing the facility and funds for this research. Ram R. Panthi is in receipt of a Teagasc Walsh Fellowship. We thank the Electron Microscopy Core Research Facility and the NanoScale Imaging and Surface Analysis Lab at the University of Utah (Salt Lake City, UT) for use of the transmission and scanning electron microscope, respectively. We are also grateful to Leprino Foods Company (Denver, CO) for supporting the Biostructure Center, part of the Western Dairy Center at Utah State University.

\section{REFERENCES}

Broome, M. C., S. E. Tan, M. A. Alexander, and B. Manser. 1998. Low-concentration-ratio ultrafiltration for cheddar cheese manufacture - Part 1: Effect on seasonal cheese composition. Aus. J. Dairy Tech. 53:5-10.

Calvo, M. M., and N. A. Espinoza. 1999. Syneresis rate of cow's, ewe's, and goat's curd. Effect of thermal treatment and ultrafiltration. J. Agric. Food Chem. 47:883-886.

Caron, A., Y. Pouliot, and D. St-Gelais. 2001. Whey syneresis differs from curd made with ultrafiltered or microfiltered milk retentate powders. Milchwissenschaft 56:387-391.

Casiraghi, E. M., C. Peri, and L. Piazza. 1987. Effect of calcium equilibria on the rate of syneresis and on the firmness of curds obtained from milk UF retentates. Milchwissenschaft 42:232-235.

Castillo, M., J. A. Lucey, T. Wang, and F. A. Payne. 2006. Effect of temperature and inoculum concentration on gel microstructure, permeability and syneresis kinetics. Cottage cheese-type gels. Int. Dairy J. 16:153-163.

Dejmek, P., and P. Walstra. 2004. The syneresis of rennet-coagulated curd. Pages 71-103 in Cheese: Chemistry, Physics and Microbiology. Vol. 1: General Aspects. 3rd ed. P. F. Fox, ed. Chapman and Hall, London, UK.

Everard, C. D., D. J. O'Callaghan, M. J. Mateo, C. P. O'Donnell, M. Castillo, and F. A. Payne. 2008. Effects of cutting intensity and stirring speed on syneresis and curd losses during cheese manufacture. J. Dairy Sci. 91:2575-2582.

Fagan, C. C., M. Castillo, F. A. Payne, C. P. O'Donnell, and D. J. O'Callaghan. 2007. Effect of cutting time, temperature, and calcium on curd moisture, whey fat losses, and curd yield by response surface methodology. J. Dairy Sci. 90:4499-4512.

Fagan, C. C., D. J. O'Callaghan, M. J. Mateo, and P. Dejmek. 2017. The syneresis of rennet-coagulated curd. Pages 145-177 in Cheese: Chemistry, Physics and Microbiology. P. L. H. McSweeney, P. F. Fox, P. D. Cotter, and D. W. Everett, ed. Academic Press, London, UK.
Gavlak, R., D. Horneck, and R. O. Miller. 2005. Plant, Soil, and Water Reference Methods for the Western Region. 3rd ed. Western Rural Development Center, Corvallis, OR.

Geng, X. L., F. W. J. van den Berg, A. N. Bager, and R. Ipsen. 2011. Dynamic visualization and microstructure of syneresis of cheese curd during mechanical treatment. Int. Dairy J. 21:711-717.

Giroux, H. J., C. Bouchard, and M. Britten. 2014. Combined effect of renneting $\mathrm{pH}$, cooking temperature, and dry salting on the contraction kinetics of rennet-induced milk gels. Int. Dairy J. 35:70-74.

Govindasamy-Lucey, S., J. J. Jaeggi, A. L. Bostley, M. E. Johnson, and J. A. Lucey. 2004. Standardization of milk using cold ultrafiltration retentates for the manufacture of Parmesan cheese. J. Dairy Sci. 87:2789-2799.

Govindasamy-Lucey, S., J. J. Jaeggi, M. E. Johnson, T. Wang, and J. A. Lucey. 2005. Use of cold ultrafiltered retentates for standardization of milks for pizza cheese: Impact on yield and functionality. Int. Dairy J. 15:941-955.

Govindasamy-Lucey, S., J. J. Jaeggi, C. Martinelli, M. E. Johnson, and J. A. Lucey. 2011. Standardization of milk using cold ultrafiltration retentates for the manufacture of Swiss cheese: Effect of altering coagulation conditions on yield and cheese quality. J. Dairy Sci. 94:2719-2730.

Grundelius, A. U., K. Lodaite, K. Ostergren, M. Paulsson, and P. Dejmek. 2000. Syneresis of submerged single curd grains and curd rheology. Int. Dairy J. 10:489-496.

Guinee, T. P., D. J. O. Callaghan, E. O. Mulholland, and D. Harrington. 1996. Milk protein standardization by ultrafiltration for Cheddar cheese manufacture. J. Dairy Res. 63:281-293.

Guinee, T. P., B. T. O'Kennedy, and P. M. Kelly. 2006. Effect of milk protein standardization using different methods on the composition and yields of Cheddar cheese. J. Dairy Sci. 89:468-482.

Guinee, T. P., P. D. Pudja, and E. O. Mulholland. 1994. Effect of milk protein standardization, by ultrafiltration, on the manufacture, composition and maturation of Cheddar Cheese. J. Dairy Res. 61:117-131.

Heino, A., J. Uusi-Rauva, and M. Outinen. 2010. Pre-treatment methods of Edam cheese milk. Effect on cheese yield and quality. LWT Food Sci. Tech. (Paris) 43:640-646.

Huber, P., B. Fertsch, R. Schreiber, and J. Hinrichs. 2001. Dynamic model system to study the kinetics of thermally-induced syneresis of cheese curd grains. Milchwissenschaft 56:549-552.

Janhøj, T., and K. B. Qvist. 2010. The formation of cheese curd. Pages 130-165 in Technology of Cheesemaking. B. A. Law and A. Y. Tamime, ed. Wiley-Blackwell, London, UK.

Johnston, K. A., M. S. Luckman, H. G. Lilley, and B. M. Smale. 1998. Effect of various cutting and stirring conditions on curd particle size and losses of fat to the whey during cheddar cheese manufacture in Ost vats. Int. Dairy J. 8:281-288.

Kaytanli, M., Y. K. Erdem, and I. M. Tamer. 1994. Factors affecting whey drainage rate of renneted skim milk gels-A kinetic approach. Milchwissenschaft 49:197-200.

Mateo, M. J., C. D. Everard, C. C. Fagan, C. P. O'Donnell, M. Castillo, F. A. Payne, and D. J. O'Callaghan. 2009a. Effect of milk fat concentration and gel firmness on syneresis during curd stirring in cheese-making. Int. Dairy J. 19:264-268.

Mateo, M. J., D. J. O'Callaghan, C. D. Everard, C. C. Fagan, M. Castillo, F. A. Payne, and C. P. O'Donnell. 2009b. Influence of curd cutting programme and stirring speed on the prediction of syneresis indices in cheese-making using NIR light backscatter. LWT Food Sci. Tech. (Paris) 42:950-955.

Mellema, M., P. Walstra, J. H. J. van Opheusden, and T. van Vliet. 2002. Effects of structural rearrangements on the rheology of rennet-induced casein particle gels. Adv. Colloid Interface Sci. 98:25-50.

Mistry, V. V., and J.-L. Maubois. 2017. Application of membrane separation technology to cheese production. Pages 677-697 in Cheese: Chemistry, Physics and Microbiology. P. L. H. McSweeney, P. F. Fox, P. D. Cotter, and D. W. Everett, ed. Academic Press, London, UK. 
Ong, L., R. Dagastine, S. Kentish, and S. Gras. 2013. Microstructure and composition of full fat Cheddar cheese made with ultrafiltered milk retentate. Foods 2:310-331.

Ong, L., R. R. Dagastine, M. A. E. Auty, S. E. Kentish, and S. L. Gras. 2011. Coagulation temperature affects the microstructure and composition of full fat Cheddar cheese. Dairy Sci. Technol. 91:739-758.

Oommen, B. S., V. V. Mistry, and M. G. Nair. 2000. Effect of homogenization of cream on composition, yield, and functionality of Cheddar cheese made from milk supplemented with ultrafiltered milk. Lait 80:77-91.

Ozturk, M., S. Govindasamy-Lucey, J. J. Jaeggi, M. E. Johnson, and J. A. Lucey. 2015. Low-sodium Cheddar cheese: Effect of fortification of cheese milk with ultrafiltration retentate and high-hydrostatic pressure treatment of cheese. J. Dairy Sci. 98:6713-6726.

Panthi, R. R., A. L. Kelly, D. Hennessy, S. McAuliffe, M. Mateo, C. O'Donnell, D. J. O'Callaghan, and J. J. Sheehan. 2018. Kinetics of moisture loss during stirring of cheese curds produced from standardised milks of cows on pasture or indoor feeding systems. Int. J. Dairy Technol. 71:663-672. https://doi.org/10.1111/1471 $-0307.12489$

Panthi, R. R., A. L. Kelly, J. J. Sheehan, K. Bulbul, A. H. Vollmer and D. J. McMahon. 2019. Influence of protein concentration and coagulation temperature on rennet-induced gelation characteris- tics and curd microstructure. J. Dairy Sci. 102:177-189. https:// doi.org/10.3168/jds.2018-15039.

Peri, C., M. Lucisano, and E. Donati. 1985. Studies on coagulation of milk ultrafiltration retentates. II. Kinetics of whey syneresis. Milchwissenschaft 40:650-652.

Qvist, K. B. 1979. Reestablishment of the original rennetability of milk after cooling, 1: The effect of cooling and LTST pasteurization of milk and renneting. Milchwissenschaft 34:467-469.

Renault, C., T. E. Gastaldi, A. Lagaude, J. L. Cuq, and B. T. delaFuente. 1997. Mechanisms of syneresis in rennet curd without mechanical treatment. J. Food Sci. 62:907-910.

Sandra, S., C. Cooper, M. Alexander, and M. Corredig. 2011. Coagulation properties of ultrafiltered milk retentates measured using rheology and diffusing wave spectroscopy. Food Res. Int. 44:951-956.

Thomann, S., A. Brechenmacher, and J. Hinrichs. 2006. Comparison of models for the kinetics of syneresis of curd grains made from goat's milk. Milchwissenschaft 61:407-411.

Thomann. S., P. Schenkel, and J. Hinrichs. 2008. Effect of homogenization, microfiltration and $\mathrm{pH}$ on curd firmness and syneresis of curd grains. LWT Food Sci. Tech. (Paris) 41:826-835.

Van Vliet, T., H. Van Dijk, P. Zoon, and P. Walstra. 1991. Relation between syneresis and rheological properties of particle gels. Colloid Polym. Sci. 269:620-627. 